\title{
EKSPLORASI ELEMEN INTEGRATED REPORTING DALAM ANNUAL REPORTS PERUSAHAAN DI INDONESIA
}

\author{
Anis Chariri dan Indira Januarti \\ Fakultas Ekonomika dan Bisnis Universitas Diponegoro \\ Email: anis_chariri@live.undip.ac.id
}

\begin{abstract}
This study aims to identify the patterns and scope of integrated reporting and to examine the effect of audit committee characteristics (expertise and meeting) on elements of integrated reporting disclosed in the annual report of companies listed on the Indonesia Stock Exchanges (IDX). This study used 170 annual reports of companies listed on the IDX as research data (not all companies have the required data). Research data were then analyzed using STATA / MP14 Software. The findings showed that the IDX-listed companies have presented annual reports in accordance with the elements of integated reporting although the scope of presentation was relatively low amounting of $51 \%$ (33 of 64 indicators). Furthermore, this study revealed that the audit committees' expertise (in accounting/ finance) and the frequency of audit committee meetings positively and significantly influenced the scope of the integrated reporting presented in the annual report of the companies
\end{abstract}

Keywords: Integrated reporting, audit committee, accounting/financial expertise, frequency of meeting, IDX

\begin{abstract}
Penelitian ini dimaksudkan untuk mengidentifikasi pola dan luas lingkup integrated reporting dan menguji pengaruh karakteristik komite audit (keahlian dan pertemuan) terhadap luas lingkup elemen integrated reporting dalam annual report perusahaan yang terdaftar di Bursa Efek Indonesia (IDX). Penelitian menggunakan 170 annual report perusahaan yang terdaftar di IDX sebagai data penelitian (tidak semua perusahaan memiliki data yang diperlukan). Data penelitian dianalisis dengan metode content analysis, statistik deskriptif dan inferensial dengan menggunakan bantuan Software STATA/MP14. Temuan penelitian menunjukkan bahwa perusahaan yang terdaftar di IDX telah menyajikan annual report sesuai dengan elemen integated reporting walaupun dengan luas penyajian yang rendah, yaitu sebesar 51\% (33 dari 64 indikator). Selanjutnya, penelitian ini menyimpulkan bahwa keahlian komite audit (dalam akuntansi/keuangan) dan frekuensi rapat komite audit berpengaruh positif terhadap luas lingkup integrated reporting.
\end{abstract}

Keywords: integrated reporting, komite audit, keahlian keuangan/akuntansi, frekuensi pertemuan, IDX

\section{PENDAHULUAN}

Integrated reporting <IR> merupakan format pelaporan keuangan terbaru yang mengutamakan transparansi dalam pelaporan kinerja perusahaan. Integrated reporting menyajikan informasi keuangan dan non-keuangan seperti faktor-faktor ekonomi, keuangan, governance, lingkungan, intangible, dan isu sosial yang jelas dan terintegrasi tentang bagaimana suatu organisasi menciptakan nilai tambah (Azam, Warraich, \& Awan, 
2011; Eccles, Krzus, \& Ribot, 2015; Morros, 2016; Soyka, 2013). (Ballou, Casey, Grenier, \& Heitger, 2012) mengatakan bahwa integrated reporting bertujuan untuk mengatasi keterbatasan pelaporan keuangan konvensional dan sustainability reporting dan diyakini mampu menyajikan perspektif bisnis yang lebih komprehensif, efektif, transparan dan terintegrasi dalam satu format laporan (Brown \& Dillard, 2014; Cheng, Green, Conradie, Konishi, \& Romi, 2014; Eccles \& Krzus, 2010; Lai, Melloni, \& Stacchezzini, 2016; Reuter \& Messner, 2015; Soyka, 2013).

Karena lingkupnya yang holistik dan terintegrasi, banyak perusahaan telah menerapkan integrated reporting, khususnya perusahaan di Afrika Selatan, Australia dan beberapa negara Eropa. Beberapa perusahaan di Indonesia juga sudah menerapkan integrated reporting, misalnya PT. Aneka Tambang Tbk, dan PT. Tambang Timah Tbk. Gambaran tersebut menunjukkan bahwa integrated reporting mudah diterapkan dan memiliki manfaat ekonomi. Namun demikian, tidak ada studi yang mengeksplorasi bagaimana integrated reporting diimplementasikan di Indonesia dan faktor apa saya yang mempengaruhi luas lingkup integrated reporting.

Riset yang selama ini ada, lebih difokuskan tatanan konseptual sehingga penerapan integrated reporting memerlukan aksi nyata bukan sekedar wacana (Adams, 2015). Lebih lanjut, Studi lainya lebih difokuskan pada manfaat, perkembangan dan tantangan yang dihadapi perusahaan dalam menerapkan integrated reporting (Burke \& Clark, 2016; Havlová, 2015). Yang menarik, temuan (Rensburg \& Botha, 2014) menunjukkan bahwa hanya sedikit stakeholder yang menggunakan integrated reporting sebagai sumber utama informasi keuangan dan investasi, dan integrated reporting hanya dipandang sebagai informasi pelengkap. Celakanya kebanyakan perusahaan memiliki pemahaman yang jelek tentang nilai tambah yang dihasilkan dari penerapan integrated reporting (Perego, Kennedy, \& Whiteman, 2016). Peneliti lainnya mencoba menginvestigasi pengaruh aspek politik dan ekonomi (Dragu \& Tiron-Tudor, 2013), sistem hokum (Frías-Aceituno, Rodríguez-Ariza, \& García-Sánchez, 2013), dan aspek kultural (García-Sánchez, Rodríguez-Ariza, \& Frías-Aceituno, 2013) terhadap keberhasilan penerapan integated reporting.

Berbagai penelitian di atas, selama ini memang memberikan kontribusi dalam pengembangan integrated reporting. Namun, riset tersebut tidak mampu mengungkap alasan yang mendorong perusahaan memiliki luas lingkup integrated reporting yang berbeda. Karakteritik corporate governance terutama komite audit diyakini dapat mempengaruhi luas lingkup integrated reporting. Riset yang menginvestigasi pengaruh karakteristik perusahaan misalnya komite audit terhadap integrated reporting diyakini penting karena komite audit seringkali dihubungkan dengan kualitas pelaporan keuangan (Bédard \& Gendron, 2010; Li, Mangena, \& Pike, 2012; Lisic, Neal, Zhang, \& Zhang, 2015). Komite audit harus berperan aktif dalam mereview laporan keuangan termasuk integrated reporting dan harus memperhatikan semua aspek yang mungkin berdampak pada integritas integrated reporting (Ahmed Haji, 2015). Selain itu, komite audit juga harus mereview pengungkapan informasi keberlanjutan dalam integrated reporting pengungkapan tersebut tidak bertentangan dengan informasi keuangan yang disajikan (King III, 2009).

Teori Agensi (agency theory) merupakan teori yang dapat digunakan untuk menjelaskan alasan mengapa komite audit diyakini dapat mempengaruhi luas lingkup integrated reporting. Dalam konteks teori Agency, organisasi pada dasarnya merupakan hubungan kontraktual (nexus of contract) antara dua pihak dimana salah satu pihak 
menjadi agen dan pihak lain bertindak sebagai prinsipal (Jensen \& Meckling, 1976). Dalam hubungan kontraktal tersebut principal (pemilik) mendelegasikan pengambilan keputusan sepenuhnya kepada manager (agen). Agar dapat mengawasi perilaku agen, diperlukan pihak lain, misalnya komite audit untuk memonitor praktek pelaporan keuangan yang dilakukan agen.

Komite Audit adalah komite pengawas di bawah dewan komisaris karena dewan komisaris dalam menjalankan tugasnya melimpahkan tanggung jawab dalam proses pelaporan perusahaan kepada komite audit (Bédard \& Gendron, 2010; Ghafran \& O'Sullivan, 2013; Li et al., 2012). Komite audit diyakini memiliki peran dalam mengurangi asimetri informasi (Akhtaruddin \& Haron, 2010; Al Daoud, Ku Ismail, \& Lode, 2015) dan akibatnya mengurangi biaya agensi (Bédard \& Gendron, 2010). Dalam konteks tata kelola perusahaan, komite audit memainkan peranan penting dalam mengawasi implementasi kebijakan keuangan dan akuntansi perusahaan (Dezoort, 1998; Ghafran \& O'Sullivan, 2013; Hayes, 2014; Spira, 1998, 1999). Oleh karena itu luas lingkup integrated reporting juga tidak dapat dilepaskan dari peran audit komite. Hal ini sejalan dengan peran audit komite dalam berbagai kebijakan perusahaan seperti pencegahan earning management (Garven, 2015; Miko \& Kamardin, 2015), kepatuhan terhadap regulasi (Bepari \& Mollik, 2015; Bryce, Ali, \& Mather, 2014), pengungkapan dan pelaporan keuangan (J. L. . Abernathy, Beyer, Masli, \& Stefaniak, 2015; Ahmed Haji, 2015; Akhtaruddin \& Haron, 2010; Tanyi \& Smith, 2015).

Beberapa penelitian menunjukkan bahwa fungsi komite audit tergantung pada beberapa faktor seperti komposisi, ukuran, kualifikasi, serta kegiatan yang dilakukan oleh komite audit (Abbott, Parker, \& Peters, 2004; Beasley \& Salterio, 2001; Carcello \& Neal, 2003; Klein, 2002; Lee \& Stone, 1997). Lebih lanjut studi oleh (Felo, Krishnamurthy, \& Solieri, 2003) tentang hubungan antara karakteristik komite audit yaitu keahlian keuangan, independensi, dan ukuran komite audit terhadap kualitas informasi keuangan memberikan hasil sebagai berikut: a) independensi komite audit dapat mencegah perusahaan dalan penyimpangan keuangan; b) keahlian keuangan anggota komite audit meningkatkan kualitas informasi keuangan yang dipublikasikan; dan c) ukuran komite audit meningkatkan kualitas informasi keuangan.

Argumen di atas menunjukkan bahwa komite audit dapat melakukan tugasnya dengan baik jika mereka memiliki kompetensi keuangan atau akuntansi dan aktif dalam memonitor kegiatan agen melalui pertemuan rutin. Oleh karena itu pola dan luas lingkup integrated reporting tidak dapat dilepaskan dari peran audit komite. Hal ini sejalan dengan peran audit komite dalam berbagai kebijakan perusahaan seperti pencegahan earning management (Garven, 2015; Miko \& Kamardin, 2015), kepatuhan terhadap regulasi (Bepari \& Mollik, 2015; Bryce et al., 2014), pengungkapan dan pelaporan keuangan (J. L. . Abernathy et al., 2015; Ahmed Haji, 2015; Akhtaruddin \& Haron, 2010; Tanyi \& Smith, 2015).

Sesuai dengan agency theory, untuk mengurangi asimetri informasi dan menjembatani kepentingan pemilik dengan manajemen, komite audit harus memiliki kompetensi atau keahlian khusus guna meningkatkan efektivitasnya. Keahlian akuntansi dan/atau keuangan merupakan hal penting bagi komite audit (J. L. . Abernathy et al., 2015; Hayes, 2014). Anggota Komite Audit dengan latar belakang keuangan dan/atau akuntansi dan memiliki pengalaman dan pelatihan cenderung mampu memahami manajemen risiko yang dihadapi perusahaan (Purcell, Francis, \& Clark, 2014). 
Banyak penelitian yang menunjukkan bahwa anggota komite audit yang memiliki pengetahuan/keahlian keuangan dan/atau akuntansi mampu membuat komite audit efektif (lihat misalnya (J. L. Abernathy, Herrmann, Kang, \& Krishnan, 2013; Albring, Robinson, \& Robinson, 2014; Badolato, Donelson, \& Ege, 2014). Jika anggota komite audit tidak memiliki keahlian untuk memahami teknis dan proses audit dan mekanisme pelaporan keuangan, maka peran pengawasannya kemungkinan akan berkurang (Al-Twaijry, Brierley, \& Gwilliam, 2002; Zhang, Zhou, \& Zhou, 2007). Konsekuensinya, komite audit yang memiliki keahlian akuntansi dan keuangan diprediksi dapat meningkatkan luas lingkup intergrated reporting. Konsekuensinya, hipotesis pertama menyatakan bahwa keahlian komite audit di bidang Akuntansi/Keuangan berpengaruh positif terhadap luas lingkup elemen integrated reporting dalam annual report perusahaan.

Pengawasan merupakan salah satu aktivitas penting dalam impelementasi good corporate governance. Agency Theory mengatakan bahwa kualitas pengawasan yang baik dapat menurunkan perilaku oportunistik manajer sehingga manajer akan bekerja untuk kepentingan para prinsipalnya. Komite audit perlu melakukan pertemuan rutin dalam melaksanakan pengawasan atas pelaporan keuangan dan pengendalian internal. Pertemuan yang teratur dan terjadwal dengan baik akan membantu komite audit dalam memonitor catatan akuntansi dan sistem pengendalian internal (Lisic et al., 2015). Pandangan sejenis disampaikan oleh (Goodwin-Stewart \& Kent, 2006; Hoque, Islam, \& Azam, 2013) bahwa pertemuan rutin memungkinkan komite audit makin efektif dalam mengawasi proses pelaporan keuangan dan pengendalian internal dan meningkatkan kualitas informasi yang dihasilkan manajemen dan kualitas audit (Louis Braiotta, 2003; Song \& Windram, 2004).

Studi lainnya juga menunjukkan bahwa anggota komite audit yang lebih sering bertemu cenderung memiliki lebih banyak waktu untuk melakukan peran pengawasan dalam pelaporan keuangan perusahaan. (Chen, Moroney, \& Houghton, 2005; Collier \& Gregory, 1999; Hoque et al., 2013; Karamanou \& Vafeas, 2005; Mangena \& Tauringana, 2008; Munro \& Buckby, 2008). Anggota komite Audit yang bertemu secara teratur sering diharapkan dapat melakukan tugas-tugas pemantauan lebih efektif daripada ang jarang melakukan pertemuan rutin. (Zhang et al., 2007) menggunakan jumlah pertemuan untuk mengukur apakah frekuensi pertemuan mempengaruhi kualitas pelaporan keuangan dan menemukan adanya korelasi positif. Atas dasar argumen tersebut, hubungan antara frekuensi rapat komite audit dengan integrated reporting dapat dihipotesiskan sebagai berikut: semakin tinggi frekuensi rapat komite audit semakin banyak elemen integrated reporting dalam annual report perusahaan.

Memang benar bahwa penerapan integrated reporting pada perusahaan di Indonesia masih bersifat sukarela, namun beberapa perusahaan sudah menerapkan integrated reporting. Oleh karena itu, penelitian ini dilakukan untuk menjawab pertanyaan sebagai berikut: Pertama, bagaimana pola dan elemen integrated reporting tercermin pada laporan tahunan perusahaan yang terdaftar di IDX? Kedua, bagaimana karakteristik komite audit dapat mempengaruhi luas lingkup elemen integrated reporting dalam annual report perusahaan yang terdaftar di IDX? Penelitian ini diyakini penting karena minimal memberikan dua kontribusi utama. Pertama, riset ini merupakan upaya pertama yang mencoba menggali pola dan luas lingkup elemen integrated reporting dalam annual report perusahaan di Indonesia, sehingga hasilnya diharapkan dapat digunakan regulator dalam mendesain model integrated reporting yang cocok untuk perusahaan di Indonesia. Kedua, penelitian ini juga berusaha mengungkap bagaimana karakteristik komite audit mempengaruhi pola dan luas lingkup integrated reporting, sehingga hasilnya dapat 
digunakan untuk mengevaluasi peran komite audit dalam mereview dan memastikan kualitas dan transparansi pelaporan keuangan.

\section{METODE}

Penelitian ini dilakukan pada perusahaan yang terdaftar di Bursa Efek Indonesia (IDX). Data sekunder diperoleh melalui penelusuran berbagai annual report perusahaan dan laporan lain yang diperlukan baik yang dipublikasikan di IDX. Sampel sebanyak 170 annual report perusahaan digunakan dalam penelitian ini mengingat tidak semua perusahaan memiliki data yang diperlukan. Variabel dependen dalam penelitian integrated reporting yang diukur dengan integrated reporting index (IRX) berdasarkan 64 item/indikator yang dikembangkan oleh (NKONKI, 2011) yaitu Ethical Leadership and Corporate Citizenship (2 indikator); Board and Directors (26 indikator); Audit Committees (11 indikator); The Governance of Risk (3 indikator); The Governance of Information Technology (1 indikator); Compliance with Laws, Codes, Rules, and Standards (1 indikator); Internal Audit (3 indikator); Governing Stakeholders Relationship (2 indikator); dan Integrated reporting disclosure (15 indikator). Jika perusahaan mengungkapkan suatu item integrated reporting maka perusahaan tersebut diberi skor satu sehingga index integrated reporting dihitung dengan membagi total item yang diungkapkan dengan total item pegungkapan (64 item).

Variabel independen terdiri Keahlian Komite Audit dan Frekuensi Pertemuan Komite Audit.Variabel keahlian komite audit (ACE) diukur berdasarkan jumlah anggota komite audit yang memiliki ahli keuangan atau akuntansi terhadap jumlah anggota komite audit keseluruhan. Variabel Frekuensi Pertemuan Komite Audit (ACM) merupakan jumlah pertemuan yang dilakukan oleh anggota komite audit dalam satu periode akuntansi dan diukur dengan jumlah total pertemuan yang dilakukan oleh komite audit dalam tahun berjalan.

Luas lingkup elemen integrated reporting dalam annual reprot dianalisis dengan statistik deskriptif. Hubungan antara komite audit dan IRX dianalisis dengan menggunakan persamaan regresi sebagai berikut:

$$
\mathrm{IRX}=\alpha+\beta_{1} \mathrm{ACE}+\beta_{2} \mathrm{ACM}+\mathrm{e}
$$

Pengujian hipotesis dilakukan dengan mengunakan level signifikansi sebesar 5\% dengan bantuan Software STATA/MP14.

\section{HASIL DAN PEMBAHASAN}

Penelitian ini dimaksudkan untuk mengidentifikasi pola dan luas lingkup elemen integrated reporting dalam annual report perusahaan di Bursa Efek Indonesia (IDX) dan menguji pengaruh karakteristik komite audit yaitu keahlian komite audit dan pertemuan komite audit terhadap luas lingkup integrated reporting. Berikut ini akan dibahas temuan penelitian. Bagian pertama membahas temuan berkaitan dengan pola dan luas lingkup elemen integrated reporting yang disajikan dalam annual report dan bagian kedua membahas temuan berkaitan dengan korelasi antara karaktersitik komite audit dengan luas lingkup integrated reporting dalam annual report perusahaan yang terdaftar di IDX. 
Pola dan Luas lingkup Integrated Reporting. Atas dasar sembilan elemen integrated reporting, content analysis digunakan untuk menghitung jumlah indikator integrated reporting yang disajikan oleh masing perusahaan dalam annual report mereka. Content analysis menghasilkan pola dan luas integrated reporting dalam annual report sebagaimana yang diungkapkan pada Gambar 1.

Berdasarkan hasil content analysis terhadap item integrated reporting yang dicantumkan dalam annual report perusahaan, terlihat bahwa perusahaan yang terdaftar di IDX memiliki pola pengungkapan yang menarik. Gambar 1 menunjukkan bahwa dilihat dari integrated reporting index (IRX), perusahaan di IDX telah menyajikan elemen integrated reporting dalam annual report mereka sebesar 51\% (33 dari 64 indikator) Elemen integrated reporting yang paling banyak diungkapkan adalah kepatuhan dengan aturan hukum (Compliance with Laws, Codes, Rules, and Standards) dengan index sebesar $91 \%$. Sebaliknya elemen integrated reporting yang paling sedikit diungkapkan perusahaan adalah integrated reporting disclosure (21\%), disusul internal audit (33\%) dan Governance of Risk (61\%). Sementara elemen lainya disajikan dalam annual report perusahaan dengan index yang cukup tinggi masing-masing: board and directors $(70 \%)$, the governance of information technology (73\%), dan audit committees (81\%). Pola dan luas lingkup elemen integrated reporting dalam annual report dapat dianalisis lebih lanjut jika dikaitkan dengan karakteristik komite audit perusahaan.



Gambar 1. Pola dan luas lingkup integrated reporting 
Uji Korelasi Karakteristik Komite Audit dan Integrated reporting. Tujuan kedua dari penelitian ini adalah untuk menguji pengaruh karakteristik komite audit yaitu keahlian akuntansi/keuangan komite audit dan pertemuan (frekuensi rapat) komite audit terhadap elemen integrated reporting yang disajikan dalam annual report. Sebelum dilakukan analisis lebih lanjut berkaitan dengan karakteristik komite audit dan Integrated reporting, maka perlu dilakukan analisis deskriptif atas variabel penelitian. Analisis deskriptif digunakan untuk menunjukkan gambaran utama dari data yang digunakan dalam penelitian ini yang mencakup nilai minimum, maksimum, mean dan standar deviasi. Hasil statistik deskriptif ditunjukkan pada Tabel 1.

Tabel 1. Statistik Deskriptif

\begin{tabular}{lccccc}
\hline Variables & Obs & Mean & Std. Dev. & Min & Max \\
\hline IRX & 170 & 0.51 & 0.12 & 0.34 & 0.80 \\
ACE & 170 & 2.38 & 1.02 & 1.00 & 6.00 \\
ACM & 170 & 6.58 & 6.29 & 1.00 & 27.00 \\
\hline
\end{tabular}

Tabel 1 menunjukkan bahwa sample perusahaan yang terdaftar di IDX melaporkan indeks integrated reporting yang relatif rendah dengan rata-rata pengungkapan sebanyak 51\% (33 dari 64 item). Selain itu, perusahaan di IDX memiliki rata-rata komite audit dengan keahlian di bidang akuntansi/keuangan berjumlah sekitar dua orang (dari maksimal 6 orang anggota). Hal ini menunjukkan bahwa perusahaan yang terdaftar di IDX memiliki jumlah anggota komite audit yang cukup dengan keahlian di bidang akuntansi / keuangan. Dari variabel frekuensi (jumlah) pertemuan komite audit, terlihat bahwa ratarata jumlah pertemuan yang diselenggarakan oleh komite audit pada perusahaan yang terdaftar di IDX yaitu 6 kali pertemuan per tahunnya (dengan maksimun jumlah pertemuan 27 kali dan minimum sekali). Deskripsi pada Tabel 1 di atas menunjukkan bahwa secara keseluruhan rata-rata frekuensi pertemuan komite audit perusahaan yang terdaftar IDX cukup baik meskipun relatif masih rendah karena berkisar antara sekali dan enam kali pertemuan per tahun.

Sementara statistik deskriptif memberikan gambaran tantang rata-rata variabel yang digunakan dalam model, penelitian ini pada dasarnya dimaksudkan untuk menguji efek variabel independen terhadap variabel dependen. Oleh karena itu, langkah selanjutanya adalah menguji pengaruh karakteristik komite audit (keahlian dan pertemuan) terhadap luas lingkup elemen integrated reporting dalam annual report perusahaan (diproksi dengan integrated reporting index). Pengujian dilakukan dengan uji regresi. Oleh karena analisis data dilakukan dengan menggunakan software STATA/MP14 yang secara otomatis menghasilkan output yang bersifat robust standard error, maka output analisis regresi dapat langsung digunakan untuk menyimpulkan pengaruh variabel independent terhadap integrated reporting. Tabel 2 menyajikan hasil regresi untuk sampel perusahan yang terdaftar di IDX.

Tabel 2 menjelaskan bahwa nilai $\mathrm{F}(3,166)=86.80 ;$ Prob $>\mathrm{F}=0.000$, yang berarti bahwa model regresi dapat digunakan untuk menguji korelasi antara integrated reporting dengan variabel penjelasnya. Model regresi menyimpulkan bahwa hipotesis pertama yang menyebutkan pengaruh keahlian komite audit terhadap integrated reporting didukung oleh data empiris. Keahlian komite audit di bidang akuntansi/keuangan secara positif mempengaruhi integrated reporting dengan nilai sig $=0,010(\mathrm{p}<0,05)$. Hipotesis kedua 
juga menegaskan secara empiris bahwa frekuensi pertemuan komite audit memiliki korelasi positif dengan integrated reporting dimana nilai sig $=0,000(\mathrm{p}<0,05)$.

Table 2. Hasil Uji Regresi: Integrated reporting = Dependen

\begin{tabular}{lcccc}
\hline \multirow{2}{*}{ Variables } & \multicolumn{4}{c}{ Regression (Robust Std. Error) } \\
\cline { 2 - 5 } & Coef. & Robust Std. Err. & $\mathrm{T}$ & $\mathrm{p}>|\mathrm{t}|$ \\
\hline Constant & 0.35 & 0.018 & 19.54 & 0.000 \\
ACE & 0.01 & 0.007 & 2.61 & $0.010^{*}$ \\
ACM & 0.01 & 0.001 & 14.17 & $0.000^{*}$ \\
\hline
\end{tabular}

$\mathrm{F}(3,166)=86.80 ;$ Prob $>\mathrm{F}=0.000 ; \mathrm{R}$-squared $=0.62 ;$ Root $\mathrm{MSE}=0.078$

Note: *) ignifican pada 5\%

\section{HASIL DAN PEMBAHASAN}

Temuan penelitian ini menunjukkan bahwa perusahaan yang terdaftar di IDX telah memasukkan elemen integrated reporting dalam annual report meskipun masih relatif rendah. Secara keseluruhan, integrated reporting index dari perusahaan yang terdaftar IDX hanya sebesar $51 \%$. Hal ini beralasan mengingat penerapan integrated reporting bagi perusahaan yang terdaftar di IDX masih bersifat wajib volunatry. Gambaran statistik deskriptif ini menunjukkan bahwa annual report perusahaan sudah berusaha menampilkan berbagai elemen integrated reporting, meskipun dengan pola dan luas lingkup integrated reporting yang berbeda. Dengan kata lain, perusahaan di IDX sudah berusaha menyajikan beberapa informasi sesuai dengan kriteria informasi yang disyaratkan dalam penyajian integrated reporting.

Pola dan luas lingkup elemen integrated reporting dalam annual report perusahaan di atas menunjukkan bahwa jika dikaitkan dengan dengan peran integrated reporting dalam mengurangi biaya agensi, perusahaan yang terdaftar di IDX telah berusaha mengurangi biaya agensi melalui pengungkapan informasi yang lebih banyak, tidak terbatas pada format laporan keuangan konvensional. Lebih lanjut, temuan penelitian ini mendukung argumen yag menyebutkan bahwa komite audit memainkan peran penting dalam mengurangi asimetri informasi (Akhtaruddin \& Haron, 2010; Al Daoud et al, 2015) dan dampaknya dapat mengurangi biaya agensi (Bedard \& Gendron 2010).

Dalam konteks korelasi antar variabel yang diuji, hasil penelitian ini menunjukkan bahwa komite audit dengan keahlian akuntansi/keuangan secara positif mempengaruhi luas lingkup elemen integrated reporting. Ini berarti bahwa semakin banyak anggota komite audit dengan keahlian akuntansi/keuangan semakin banyak item (informasi) integrated reporting disajikan dalam annual report. Temuan ini logis mengingat sebagai bagian dari mekanisme tata kelola perusahaan, komite audit bertanggung jawab untuk mengawasi pelaporan keuangan suatu entitas. Konsekuensinya, anggotanya harus memiliki keahlian yang memadai di bidang akuntansi/keuangan (Abernathy et al., 2015; Hayes, 2014;Hamid et al., 2015). Selain itu, anggota komite audit dengan keahlian akuntansi/keuangan cenderung cepat merespon perubahan dalam lingkungan bisnis dan inovasi (Badolato et al., 2014; Goodwin, 2003) dan memiliki kemampuan dalam menilai risiko perusahaan (Purcell et al., 2014). Temuan ini konsisten dengan teori agensi yang mengklaim bahwa untuk mengurangi asimetri informasi dan menyelaraskan kepentingan agen dengan kepentingan prinsipal, anggota komite audit harus memiliki keahlian di 
bidang akuntansi / keuangan. Keahlian akuntansi / keuangan menjadi elemen penting untuk memastikan bahwa komite audit melaksanakan peran mereka secara efektif seperti yang diklaim oleh peneliti lain (Abernathy et al., 2013; Albring et al., 2014; Badolato et al., 2014). Temuan ini juga konsisten dengan penelitian Dhaliwal et al. (2010).

Frekuensi rapat (pertemuan) komite audit juga mempengaruhi elemen integrated reporting yang disajikan dalam annual report. Semakin sering komite audit menyelengarakan rapat semakin banyak item integrated reporting yang disajikan dalam annual report. Keterlibatan aktif anggota komite audit dalam rapat yang dijadwalkan secara rutin memungkinkan mereka untuk membahas isu-isu yang berkaitan dengan kegiatan perusahaan termasuk isu integrated reporting. Hal ini beralasan, mengingat rutinitas pertemuan memungkinkan komite audit untuk mengawasi dengan lebih efektif catatan akuntansi dan kualitas pengendalian internal (Lisic et al., 2015; Goodwin-Stewart \& Kent, 2006; Hoque et al., 2013). Selain itu, frekuensi rapat komite audit dapat mendorong perusahaan untuk meningkatkan kualitas informasi akuntansi dan kualitas audit (Louis Braiotta, 2003; Song \& Windram, 2004). Temuan ini sejalan dengan penelitian Zhang et al., (2007) yang menemukan bahwa frekuensi rapat komite audit mempengaruhi kualitas pelaporan keuangan dan ada korelasi positif antara kedua variable tersebut. Penelitian lain melaporkan bahwa anggota komite audit yang sering melakukan rapat yang terjadwal memiliki lebih banyak waktu untuk melakukan peran pengawasan dalam pelaporan keuangan dibandingkan dengan anggota komite audit yang jarang melakukan rapat secara teratur (Chen et al., 2005; Collier \& Gregory, 1999; Hoque et al., 2013; Karamanou \& Vafeas, 2005; Mangena \& Tauringana, 2008; Munro \& Buckby, 2008). Singkatnya, elemen integrated reporting dalam annual report akan meningkat bila komite audit aktif melakukan pertemuan rutin dan terjadwal.

\section{PENUTUP}

Simpulan. Penelitian ini dilatarbelakangi oleh ketidakpuasan dengan praktik pelaporan keuangan tradisional yang hanya berfokus pada data historis dan informasi keuangan. Ketidakpuasan terhadap laporan tahunan telah menyebabkan munculnya pelaporan terintegrasi, yang mampu memberikan informasi yang lebih holistik dan terpadu (yaitu informasi keuangan dan non keuangan serta kinerja historis dan masa depan) dari sebuah perusahaan. Tujuan dari penelitian ini adalah untuk mengidentifikasi pola dan luas lingkup elemen integrated reporting dalam annual report dan menguji pengaruh karakteristik komite audit (keahlian komite audit dan frekuensi pertemuan komite audit) terhadap luas lingkup elemen integrated reporting dalam annual report. Berdasarkan data empiris, studi ini menemukan bahwa perusahaan yang terdaftar di Bursa Efek Indonesia hanya memiliki integrated reporting index sebesar 51\% (33 dari 64 indikator). Artinya, annual report perusahaan yang terdaftar di IDX belum banyak menyajikan informasi yang dikehendaki dalam integrated reporting.

Penelitian ini memberikan kontribusi temuan baru yang menarik berkaitan dengan isu-isu integrated reporting. Pertama, karakteristik unik komite audit secara signifikan mempengaruhi luas lingkup integrated reporting. Temuan peneltian ini memberikan kontribusi baru pada temuan-temuan penelitian sebelumnya, yang kebanyakan mengklaim bahwa integrated reporting dipengaruhi oleh faktor politik dan ekonomi (Dragu \& TironTudor, 2013), sistem hukum (Frías-Aceituno et al., 2013), dan faktor budaya (GarcíaSánchez et al., 2013). 
Dalam kaitan dengan korelasi antara karakteristik komite audit dan integrated reporting, penelitian ini menyimpulkan bahwa keahlian komite audit (dalam akuntansi/keuangan) berpengaruh positif terhadap integrated reporting. Hasil ini menunjukkan bahwa semakin banyak anggota komite audit yang memiliki keahlian akuntansi / keuangan semakin banyak jumlah elemen integrated reporting yang dimasukkan dalam annual report. Oleh karena integrated reporting dapat mengubah pandangan manajemen dan stakeholders, maka perusahaan perlu meningkatkan jumlah anggota komite audit yang memiliki keahlian akuntansi/keuangan. Keahlian tersebut dapat meningkatkan kemampuan anggota komite audit dalam memantau proses pelaporan keuangan, terutama pola dan luas lingkup elemen integrated reporting dalam annual report

Kedua, berkaitan dengan frekuensi rapat komite audit, penelitian ini menemukan bukti empiris bahwa frekuensi pertemuan komite audit secara empiris memiliki korelasi positif dan signifikan dengan luas lingkup integrated reporting. Hasil penelitian menunjukkan bahwa semakin intens komite audit mengadakan rapat terjadwal, maka semakin efektif peran mereka dalam memonitor penyusunan dan penyajian integrated reporting dan konsekuensinya semakin banyak elemen integrated reporting dalam annual report perusahaan. Rapat komite audit merupakan media komunikasi yang efektif bagi anggota komite audit untuk berbagi pandangan dan keahlian mereka dalam pelaporan keuangan terutama berkaitan dengan integrated reporting. Oleh karena itu, anggota komite audit perlu mengadakan rapat yang lebih teratur dan terjadwal. Sebagaimana isu pertemuan komite audit di negara lain, misal Amerika dan Inggris (Collier \& Gregory, 1999; McMullen, 1996), komite audit perusahaan go publik perlu mengadakan pertemuan rutin setidaknya empat kali dalam setahun.

Meskipun riset ini mampu memberi temuan baru dan kontribusi menarik bagi pengetahuan dan praktek akuntansi (khususnya dalam konteks isu-isu pelaporan bisnis), studi ini memiliki beberapa keterbatasan. Kelemahan pertama adalah bahwa penelitian ini menggunakan sampel yang terbatas karena beberapa perusahaan tidak memiliki data yang dibutuhkan dalam tahunan. Keterbatasan sampel ini dapat mempengaruhi kualitas hasil penelitian, terutama untuk tujuan generalisasi. Kedua, temuan penelitian ini hanya berlaku untuk dua karakteristik komite audit yaitu keahlian komite audit dan frekuensi pertemuan komite audit. Ini berarti bahwa penelitian selanjutnya perlu mempertimbangkan faktorfaktor lain seperti kualitas auditor eksternal, efektivitas audit internal, jenis industri, ukuran perusahaan, dan struktur kepemilikan.

\section{DAFTAR RUJUKAN}

Abbott, L. J., Parker, S., \& Peters, G. F. (2004) "Audit Committee Characteristics and Restatements". AUDITING: A Journal of Practice $\{\&\}$ Theory, 23(1), 69-87. http://doi.org/10.2308/aud.2004.23.1.69

Abernathy, J. L. ., Beyer, B. ., Masli, A. ., \& Stefaniak, C. M. . (2015) "How the source of audit committee accounting expertise influences financial reporting timeliness". Current Issues in Auditing, 9(1), P1-P9. http://doi.org/10.2308/ciia-51030

Abernathy, J. L., Herrmann, D., Kang, T., \& Krishnan, G. V. (2013) "Audit committee financial expertise and properties of analyst earnings forecasts". Advances in Accounting, 29(1), 1-11. http://doi.org/http://dx.doi.org/10.1016/j.adiac.2012.12.001

Adams, C. A. (2015) "The International Integrated Reporting Council: A call to action". 
Critical Perspectives on Accounting, 27, 23-28. http://doi.org/10.1016/j.cpa.2014.07.001

Ahmed Haji, A. (2015) "The role of audit committee attributes in intellectual capital disclosures: Evidence from Malaysia". Managerial Auditing Journal, 30(8-9), 756784. http://doi.org/10.1108/MAJ-07-2015-1221

Akhtaruddin, M., \& Haron, H. (2010) "Board ownership, audit committees' effectiveness and corporate voluntary disclosures". Asian Review of Accounting, 18(1), 68-82. http://doi.org/10.1108/13217341011046015

Al-Twaijry, A. A. M., Brierley, J. A., \& Gwilliam, D. R. (2002) "An Examination of the Role of Audit Committees in the Saudi Arabian Corporate Sector". Corporate Governance: An International Review, 10(4), 288-297. http://doi.org/10.1111/14678683.00293

Al Daoud, K. A., Ku Ismail, K. N. I., \& Lode, N. A. (2015) "The impact of internal corporate governance on the timeliness of financial reports of jordanian firms: Evidence using audit and management report lags". Mediterranean Journal of Social Sciences, 6(1), 430-442. http://doi.org/10.5901/mjss.2015.v6n1p430

Albring, S., Robinson, D., \& Robinson, M. (2014) "Audit committee financial expertise, corporate governance, and the voluntary switch from auditor-provided to nonauditor-provided tax services". Advances in Accounting, 30(1), 81-94. http://doi.org/http://dx.doi.org/10.1016/j.adiac.2013.12.007

Azam, Z., Warraich, K. M., \& Awan, S. H. (2011) "One Report: Bringing Change in Corporate Reporting through integration of Financial and Non-Financial Performance Disclosure". International Journal of Accounting and Financial Reporting, 1(1), 5072. http://doi.org/10.5296/ijafr.v1i1.831

Badolato, P. G., Donelson, D. C., \& Ege, M. (2014) "Audit committee financial expertise and earnings management: The role of status". Journal of Accounting and Economics, $58(2-3)$, http://doi.org/http://dx.doi.org/10.1016/j.jacceco.2014.08.006

208-230.

Ballou, B., Casey, R. J., Grenier, J. H., \& Heitger, D. L. (2012) "Exploring the Strategic Integration of Sustainability Initiatives: Opportunities for Accounting Research". Accounting Horizons, 26(2), 265-288. http://doi.org/10.2308/acch-50088

Beasley, M. S., \& Salterio, S. E. (2001) "The Relationship between Board Characteristics and Voluntary Improvements in Audit Committee Composition and Experience". Contemporary Accounting Research, 18(4), 539-570. http://doi.org/10.1506/RM1JA0YM-3VMV-TAMV

Bédard, J., \& Gendron, Y. (2010) "Strengthening the Financial Reporting System: Can Audit Committees Deliver?", International Journal of Auditing, 14(2), 174-210. http://doi.org/10.1111/j.1099-1123.2009.00413.x

Bepari, M. K., \& Mollik, A. T. (2015) "Effect of audit quality and accounting and finance backgrounds of audit committee members on firms' compliance with IFRS for goodwill impairment testing". Journal of Applied Accounting Research, 16(2), 196220. http://doi.org/10.1108/JAAR-05-2013-0038

Brown, J., \& Dillard, J. (2014) "Integrated reporting: On the need for broadening out and opening up". Accounting, Auditing and Accountability Journal, 27(7), 1120-1156. http://doi.org/10.1108/AAAJ-04-2013-1313

Bryce, M., Ali, M. J., \& Mather, P. R. (2014) "Accounting quality in the pre-/post-IFRS adoption periods and the impact on audit committee effectiveness - Evidence from 
Australia", Pacific-Basin Finance Journal, 35, 163-181. http://doi.org/10.1016/j.pacfin.2014.12.002

Burke, J. J., \& Clark, C. E. (2016) "The business case for integrated reporting: Insights from leading practitioners, regulators, and academics". Business Horizons. http://doi.org/10.1016/j.bushor.2016.01.001

Carcello, J. V, \& Neal, T. L. (2003) "Audit Committee Independence and Disclosure: choice for financially distressed firms". Corporate Governance: An International Review, 11(4), 289-299. http://doi.org/10.1111/1467-8683.00327

Chen, Y. M., Moroney, R., \& Houghton, K. (2005) "Audit committee composition and the use of an industry specialist audit firm". Accounting \& Finance, 45(2), 217-239. http://doi.org/10.1111/j.1467-629x.2004.00136.x

Cheng, M., Green, W., Conradie, P., Konishi, N., \& Romi, A. (2014) "The International Integrated Reporting Framework: Key Issues and Future Research Opportunities". Journal of International Financial Management \& Accounting, 25(1), 90-119. http://doi.org/10.1111/jifm.12015

Collier, P., \& Gregory, A. (1999) "Audit committee activity and agency costs". Journal of Accounting and Public Policy, 18(4-5), 311-332. http://doi.org/http://dx.doi.org/10.1016/S0278-4254(99)00015-0

Dezoort, F. T. (1998) "An analysis of experience effects on audit committee members' oversight judgments". Accounting, Organizations and Society, 23(1), 1-21. http://doi.org/http://dx.doi.org/10.1016/S0361-3682(97)00029-9

Dragu, I.-M., \& Tiron-Tudor, A. (2013) "The Integrated Reporting Initiative from an Institutional Perspective: Emergent Factors". Procedia - Social and Behavioral Sciences, 92, 275-279. http://doi.org/10.1016/j.sbspro.2013.08.672

Eccles, R. G., \& Krzus, M. P. (2010) One Report: Integrated Reporting for a Sustainable Strategy. (W. Sons, Ed.). New York, NY.

Eccles, R. G., Krzus, M. P., \& Ribot, S. (2015) "Meaning and Momentum in the Integrated Reporting Movement". Journal of Applied Corporate Finance, 27(2), 8 17. http://doi.org/10.1111/jacf.12113

Felo, A. J., Krishnamurthy, S., \& Solieri, S. A. (2003) "Audit Committee Characteristics and the Perceived Quality of Financial Reporting: An Empirical Analysis", Available at SSRN:, April. http://doi.org/http://dx.doi.org/10.2139/ssrn.401240

Frías-Aceituno, J. V. V, Rodríguez-Ariza, L., \& García-Sánchez, I. M. M. (2013) "Is integrated reporting determined by a country's legal system? An exploratory study", Journal of Cleaner Production, 44, 45-55. http://doi.org/10.1016/j.jclepro.2012.12.006

García-Sánchez, I.-M., Rodríguez-Ariza, L., \& Frías-Aceituno, J.-V. (2013) "The cultural system and integrated reporting". International Business Review, 22(5), 828-838. http://doi.org/10.1016/j.ibusrev.2013.01.007

Garven, S. (2015) "The effects of board and audit committee characteristics on real earnings management: Do boards and audit committees play a role in its promotion or constraint?", Academy of Accounting and Financial Studies Journal, 19(1), 67-84.

Ghafran, C., \& O'Sullivan, N. (2013) "The Governance Role of Audit Committees: Reviewing a Decade of Evidence". International Journal of Management Reviews, 15(4), 381-407. http://doi.org/10.1111/j.1468-2370.2012.00347.x

Goodwin-Stewart, J., \& Kent, P. (2006) "Relation between external audit fees, audit committee characteristics and internal audit". Accounting \& Finance, 46(3), 387-404. 
http://doi.org/10.1111/j.1467-629X.2006.00174.x

Goodwin, J. (2003) "The Relationship Between the Audit Committee and the Internal Audit Function: Evidence from Australia and New Zealand". International Journal of Auditing, 7(3), 263-278. http://doi.org/10.1046/j.1099-1123.2003.00074.x

Hamid, F. Z. A., Shafie, R., \& Othman, Z. (2015) The "Cognitive experience, area of business, responsiveness and engagement" conceptual framework for integrated reporting. Advanced Science Letters, 21(6), 1791-1793. http://doi.org/10.1166/asl.2015.6223

Havlová, K. (2015) "What Integrated Reporting Changed: The Case Study of Early Adopters", Procedia Economics and Finance, 34, 231-237. http://doi.org/10.1016/S2212-5671(15)01624-X

Hayes, R. M. (2014) "Discussion of "Audit committee financial expertise and earnings management: The role of status" by Badolato, Donelson, and Ege (2014)", Journal of Accounting and Economics, 58(2-3), 231-239. http://doi.org/http://dx.doi.org/10.1016/j.jacceco.2014.08.005

Hoque, M. Z., Islam, M. D. R., \& Azam, M. N. (2013) "Board Committee Meetings and Firm Financial Performance: An Investigation of Australian Companies". International Review of Finance, 13(4), 503-528. http://doi.org/10.1111/irfi.12009

Jensen, M. C., \& Meckling, W. H. (1976) "Theory of the Firm: Managerial Behavior, Agency Costs and Ownership Structure". Journal of Financial Economics, 3(4). http://doi.org/http://dx.doi.org/10.2139/ssrn.94043

Karamanou, I., \& Vafeas, N. (2005) "The Association between Corporate Boards, Audit Committees, and Management Earnings Forecasts: An Empirical Analysis", Journal of Accounting Research, 43(3), 453-486. http://doi.org/10.1111/j.1475679X.2005.00177.x

Klein, A. (2002) "Audit committee, board of director characteristics, and earnings management". Journal of Accounting and Economics, 33(3), 375-400. http://doi.org/http://dx.doi.org/10.1016/S0165-4101(02)00059-9

Lai, A., Melloni, G., \& Stacchezzini, R. (2016) "Corporate Sustainable Development: Is "Integrated Reporting" a Legitimation Strategy?", Business Strategy and the Environment, 25(3), 165-177. http://doi.org/10.1002/bse.1863

Lee, T., \& Stone, M. (1997) "Economic Agency and Audit Committees: Responsibilities and Membership Composition", International Journal of Auditing, 1(2), 97-116. http://doi.org/10.1111/1099-1123.00016

Li, J., Mangena, M., \& Pike, R. (2012) "The effect of audit committee characteristics on intellectual capital disclosure", The British Accounting Review, 44(2), 98-110. http://doi.org/http://dx.doi.org/10.1016/j.bar.2012.03.003

Lisic, L. L., Neal, T. L., Zhang, I. X., \& Zhang, Y. (2015) "CEO Power, Internal Control Quality, and Audit Committee Effectiveness in Substance Versus in Form". Contemporary Accounting Research, n/a----n/a. http://doi.org/10.1111/19113846.12177

Louis Braiotta, J. (2003) "An exploratory study of adopting requirements for audit committees for non US commercial bank registrants: an empirical analysis of foreign equity investment". Managerial Auditing Journal, 18(6/7), 456-464. http://doi.org/10.1108/02686900310482605

Mangena, M., \& Tauringana, V. (2008) "Audit Committees and Voluntary External Auditor Involvement in UK Interim Reporting". International Journal of Auditing, 
12(1), 45-63. http://doi.org/10.1111/j.1099-1123.2008.00369.x

McMullen, D. A. (1996) "Audit Committee Performance: An Investigation of the Consequences With Audit Committees", Auditing A Journal of Practice \& Theory, 15(1), 87-103.

Miko, N. U., \& Kamardin, H. (2015) Impact of Audit Committee and Audit Quality on Preventing Earnings Management in the Pre- and Post- Nigerian Corporate Governance Code 2011. Procedia - Social and Behavioral Sciences, 172, 651-657. http://doi.org/10.1016/j.sbspro.2015.01.415

Morros, J. (2016) "The integrated reporting: A presentation of the current state of art and aspects of integrated reporting that need further development. Intangible Capital, 12(1), 336-356. http://doi.org/10.3926/ic.700

Munro, L., \& Buckby, S. (2008) "Audit Committee Regulation in Australia: How Far Have We Come?", Australian Accounting Review, 18(4), 310-323. http://doi.org/10.1111/j.1835-2561.2008.0020.x

NKONKI. (2011) Integrated Reporting Checklist.

Perego, P., Kennedy, S., \& Whiteman, G. (2016) "A lot of icing but little cake? taking integrated reporting forward", Journal of Cleaner Production, 136(Part A), 53-64. http://doi.org/10.1016/j.jclepro.2016.01.106

Purcell, A. J., Francis, R. D., \& Clark, C. (2014) Audit Committee Effectiveness in Victorian Local Government. Australian Accounting Review, 24(4), 339-369. http://doi.org/10.1111/auar.12070

Rensburg, R., \& Botha, E. (2014) Is Integrated Reporting the silver bullet of financial communication? A stakeholder perspective from South Africa. Public Relations Review, 40(2), 144-152. http://doi.org/10.1016/j.pubrev.2013.11.016

Reuter, M., \& Messner, M. (2015) "Lobbying on the integrated reporting framework: An analysis of comment letters to the 2011 discussion paper of the IIRC". Accounting, Auditing and Accountability Journal, 28(3), 365-402. http://doi.org/10.1108/AAAJ03-2013-1289

Song, J., \& Windram, B. (2004) "Benchmarking Audit Committee Effectiveness in Financial Reporting". International Journal of Auditing, 8(3), 195-205. http://doi.org/10.1111/j.1099-1123.2004.00090.x

Soyka, P. A. (2013) "The International Integrated Reporting Council (IIRC) Integrated Reporting Framework: Toward Better Sustainability Reporting and (Way) Beyond". Environmental Quality Management, 23(2), 1-14. http://doi.org/10.1002/tqem.21357

Spira, L. (1998) An Evolutionary Perspective on Audit Committee Effectiveness. Corporate Governance: An International Review, 6(1), 29-38. http://doi.org/10.1111/1467-8683.00077

Spira, L. (1999) Independence in Corporate Governance: the Audit Committee Role. Business Ethics: A European Review, 8(4), 262-273. http://doi.org/10.1111/14678608.00160

Tanyi, P. N., \& Smith, D. B. (2015) Busyness, expertise, and financial reporting quality of audit committee chairs and financial experts. Auditing, 34(2), 59-89. http://doi.org/10.2308/ajpt-50929

Zhang, Y., Zhou, J., \& Zhou, N. (2007) "Audit committee quality, auditor independence, and internal control weaknesses". Journal of Accounting and Public Policy, 26(3), 300-327. http://doi.org/http://dx.doi.org/10.1016/j.jaccpubpol.2007.03.001 